MarkETING AND BRANDING
RESEARCH $\begin{gathered}\text { INDUSTRIAL } \\ \text { MANAGEMENT } \\ \text { INSTITUTE }\end{gathered}$

\title{
Location and key success factors of special economic zone in Thailand
}

\author{
Patcharee Pakdeenurit*, Nanthi Suthikarnnarunai, Wanchai Rattanawong
}

University of the Thai Chamber of Commerce

\begin{abstract}
Keywords:

Special Economic

Zone (SEZ), Key

Success Factors,

Thailand

Correspondence: nailleks@gmail.com

This paper proposes a selection of different types of Special Economic Zone (SEZ) in Thailand. Following this, the locations and key success factors of SEZs in Thailand are also provided. The first part of the paper presents all factors that are analytical or essential to the success of all types of SEZ in the world by re-examining all literature which can be found in most of the academic databases. All of those factors from the review then underwent the correlation test. The regression model with Ordinary Least Square method is created in this step. The result of the test indicated that there are eight factors which were found to be correlated to the success or survival of SEZs around the world. These eight factors are location advantage and macroeconomic of the country, industrial investment support, investment cost and value of trade, skill levels and availability of human resource, management and service, government policies, law and regulation, and stability and consistency of the government. Twenty-eight provinces from seventy-seven provinces across the country in Thailand were then selected because of two reasons, namely the government policy in promoting special economic area in Thailand and the consensus of experts from Delphi Technique. Lastly, all selected provinces are tested using the model provided in the mentioned steps. The results reveal that the most appropriate types of SEZ in Thailand are the Export Processing Zone, Specialized Zone, and Freeport Zone. The research indicates that Bangkok, Trat, Pathumthani, Chonburi, Phuket, Suratthani, Udonthani, and Srakaew are the eight provinces which have such perfect environments and factors that contribute to the success of SEZ in Thailand.
\end{abstract}

(C)AIMI Journals

\section{Introduction}

The first Special Economic Zone (SEZ) was established in 1937 in New York, the United States of America (USA) (Office of Commercial Affairs, Thai trade center Chicago, 2012). 
The other name of SEZ is "Foreign Trade Zone" (FTZ). In 1942, USA invested in creating the SEZ in Puerto Rico, since then other countries have also initiated SEZs, though might be in various names. Iceland and Taiwan established SEZs in 1960 and India established SEZ named "Export Processing Zone" in 1980. One of the most well-known SEZ is Shenzhen Special Economic Zone which established in China in 1980 (Office of Commercial Affairs, Thai trade center Mumbai, 2012; Office of Commercial Affairs, Royal Thai Embassy Beijing China, 2012). Up to now Special Economic Zones have been established in more than 135 countries all around the world. In USA, the pioneer of SEZ, has 257 areas of FTZ and 545 areas of FTZ Subzones (Bernsein, 2012; Farole, 2008).

A Special Economic Zone is defined as an area with special privileges which is established specifically by any country to attract foreign business investment in the country. The privileges might contain a particular investment policy or rule or regulations such as a tax easing, a financial support, issuance of work for foreign workers, and special support in infrastructure (for example in the customs, one stop service, single window, electricity, water supply). The businesses which have been promoted under Special Economic Zone include industry, agriculture, commerce, tourism, services or any other operation supporting a Free Trade Area (Farole \& Akinici, 2011). The current study proposes a selection of different types of Special Economic Zone (SEZ) in Thailand. Moreover, the locations and key success factors of SEZs in Thailand are also provided.

\section{The Literature Review}

\section{Key Success Factors of Special Economic Zone}

For developing countries, Special Economic Zones (SEZ) commonly involved both a policy and infrastructure rationales. In terms of policy, the SEZ can be a practical tool as part of a general overall economic growth strategy to increase industry competitiveness and attract Foreign Direct Investment (FDI). Through SEZ, governments focus to expand and enlarge exports while retaining border protection to generate jobs and to regulate new policies and approaches (for example in customers, legal, labor, and public private partnership aspects). SEZ also permits well-organized government controlling of enterprise, provision of off-site infrastructure, and environmental controls (Wang, 2010).

The formation of SEZ has restrictions that must be percieved because it might generate a long term influence such as environment pollution (Wang, Ren, Guo, \& Chen, 2012; Jiang, Sun, \& Liu, 2010). Some items including human rights, Security or Corporate Social Responsibility (CSR) should be integrated in every step in forming SEZ. However, SEZ also creates benefits as well. According to Dobronogov and Farole (2012), key criteria to consider in establishing SEZ include the location advantage and macroeconomic of country, industrial investment support, investment cost and value of trade, skill levels and availability of human resource, management and service, government policy, laws and regulations, and stability and consistency of the government.

\section{Mathematic Model}

According to the literature review (Anitha, 2000; Aradhna, 2007; Farole \& Akinici, 2011; Guo, 2010; Raheem, 2011; Ray, 2012; Tang, Selvanathan, \& Selvanathan, 2008; Tsuneishi, 
2008; Wang, 2010; Zhu, 1994), academic documents, journals, information from internet, as well as the data and statistics from the World Bank for Special Economic Zone establishment, there are some conditions and limitations which have to be realized and focused on. If those are neglected or over looked, it will have long term effects which results in increase expenses for the management. The procedures of Special Economic Zone establishment can be concluded in three stages: Stage 1 refers to analyzing the success factors and determine the variables used for measuring the success; Stage 2 indicates the test of relationships among the variables; and Stage 3 presents the test of factors of each country which affects the Special Economic Zone. The details are as follows.

\section{Key success factor analysis process}

Concerning the analysis of key success factor in establishing the Special Economic Zone, it is found that there are 8 factors which cover 3 aspects that include international environments, domestic conditions, and role of the state. These affect the Special Economic Zone establishment as shown in Figure 1.

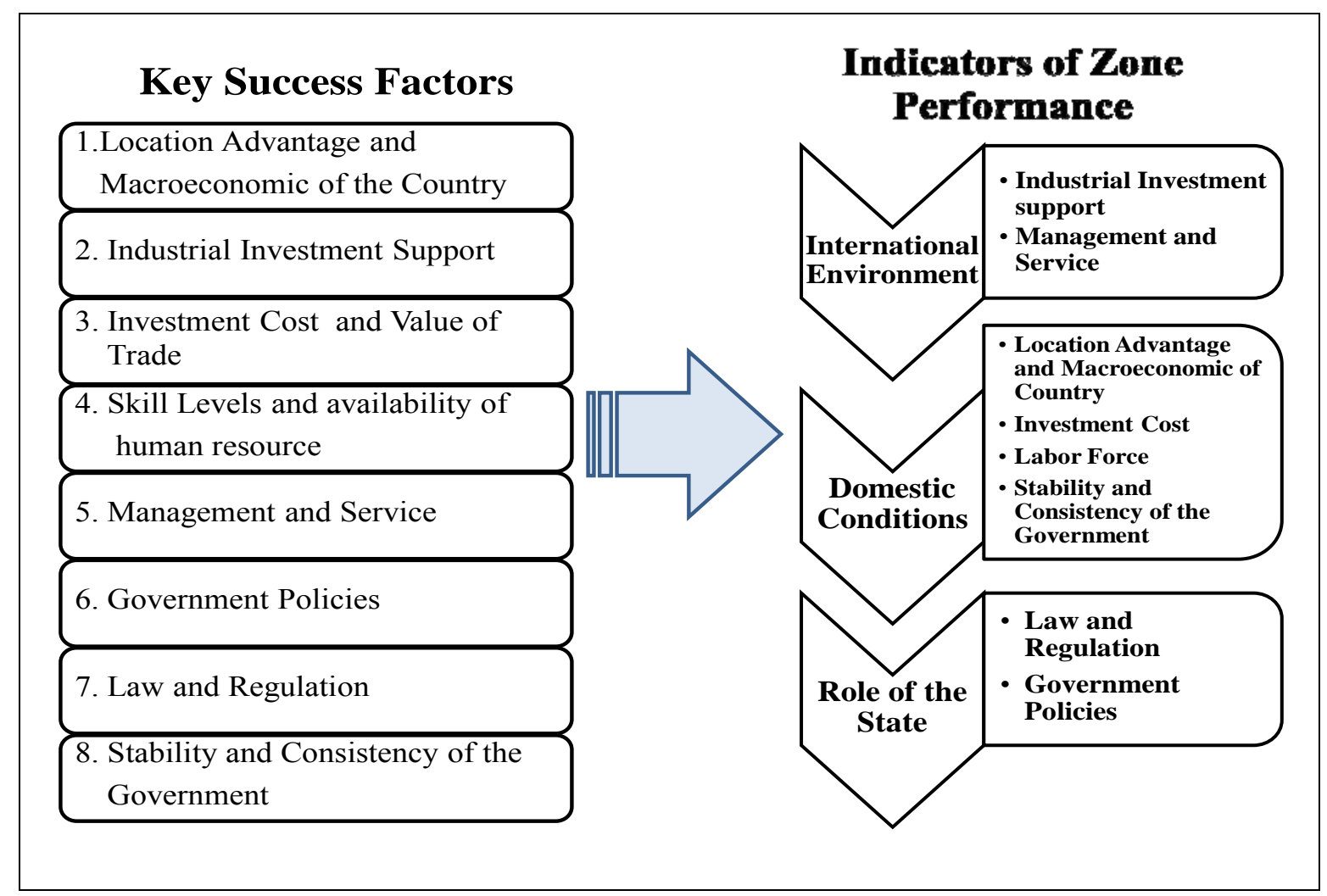

Figure. 1. Key success factors for SEZ

According to Figure 1, the variables which affect the success of Special Economic Zone establishment can be determined by determining the Foreign Direct Investment: FDI is a dependent variable. There are 8 main independent variables which include location advantage and macroeconomic of country, industrial investment support, investment cost and value of trade, skill levels and availability of human resource, management and service, government policy, law and regulation, and stability and consistency of the government. These independent variables consist of 30 sub-variables which involve Group 1, namely air transport, internet users, railway, rail line, telephone, 
mobile cell, urban population, agriculture, improved water, gross domestic product; Group 2 such as market capitalization, inflation, and consumption; Group 3 including trade, import, export; Group 4 containing labor force and population; Group 5, namely high technology, research and development, electric, and technician; Group 6 such as tax on good, tariff, tax revenue, and emission; Group 7 involving trademark application; and Group 8 such as claim of government and portfolio equity.

$$
\begin{aligned}
& \mathrm{Y}=\mathrm{FDI} \\
& +++++-++ \\
& \mathrm{QX}_{\mathrm{t}}=\mathrm{f}\left(\mathrm{Lo}_{\mathrm{t}}, \mathrm{In}_{\mathrm{t}}, \mathrm{Co}_{\mathrm{t}}, \mathrm{Sk}_{\mathrm{t}}, \mathrm{Ma}_{\mathrm{t}}, \mathrm{Go}_{\mathrm{t}}, \mathrm{La}_{\mathrm{t}}, \mathrm{St}_{\mathrm{t}}\right)
\end{aligned}
$$

Parameters

Dependent Variable: FDI = Foreign Direct Investment

Independent Variable: The variable can be determined to substitute as follows:

Lo $=$ Location advantage and Macroeconomic of country

In $=$ Industrial investment support

$\mathrm{Co}=$ Investment cost and Value of trade

Sk $=$ Skill levels and Availability of human resource

$\mathrm{Ma}=$ Management and Service

$\mathrm{Go}=$ Government Policies

$\mathrm{La}=$ Laws and Regulations

$\mathrm{St}=$ Stability and Consistency of the government

\section{The Test of Relationships between the Independent Variables and Dependent Variable}

The correlation analysis of the dependent variables with 30 independent variables is conducted by using the data of 3 model countries, namely the United States, China, and India. Moreover, the data of the 9 other countries including Canada, Mexico, Japan, Korea Rep., Singapore, Indonesia, Malaysia, Philippines, and Thailand is also used. The details are shown in the Table 1.

Table 1

Variables Used to SEZ Model

\begin{tabular}{ll}
\hline \multicolumn{1}{c}{ Independent Variable: Foreign Direct Investment (FDI) } \\
\hline \multicolumn{1}{c}{ Dependent Variables } & Indicators/Analyzers \\
\hline 1. Location Advantage and Macroeconomic of Country (Lo) & Gross Domestic Product (GDP) \\
2. Industrial Investment Support (In) & Market Capitalization \\
3. Investment Cost (Co) & Trade \\
4. Skill Levels and Availability of Human Resource (Sk) & Labor Force \\
5. Management and Service (Ma) & R\&D \\
6. Government Policies (Go) & Tariff \\
7. Law and Regulation (La) & Trademark Application \\
8. Stability and Consistency of the Government (St) & Portfolio Equity \\
\hline
\end{tabular}

Source: World Bank's Indicator

Concerning Table 1, the above test results leave 8 variables which have the correlation with Foreign Direct Investment (FDI) that include GDP, market capitalization, trade, labor force, R\&D, tariff, trademark application, and portfolio equity. Some variables have to be eliminated to avoid the autocorrelation problem. It involves the relationship of determination on 8 key success factors for Special Economic Zone establishment and the determination of dependent variables and independent 
variables. This depends on the database from the indicator of the World Bank as illustrated in the flowchart in Figure 2.

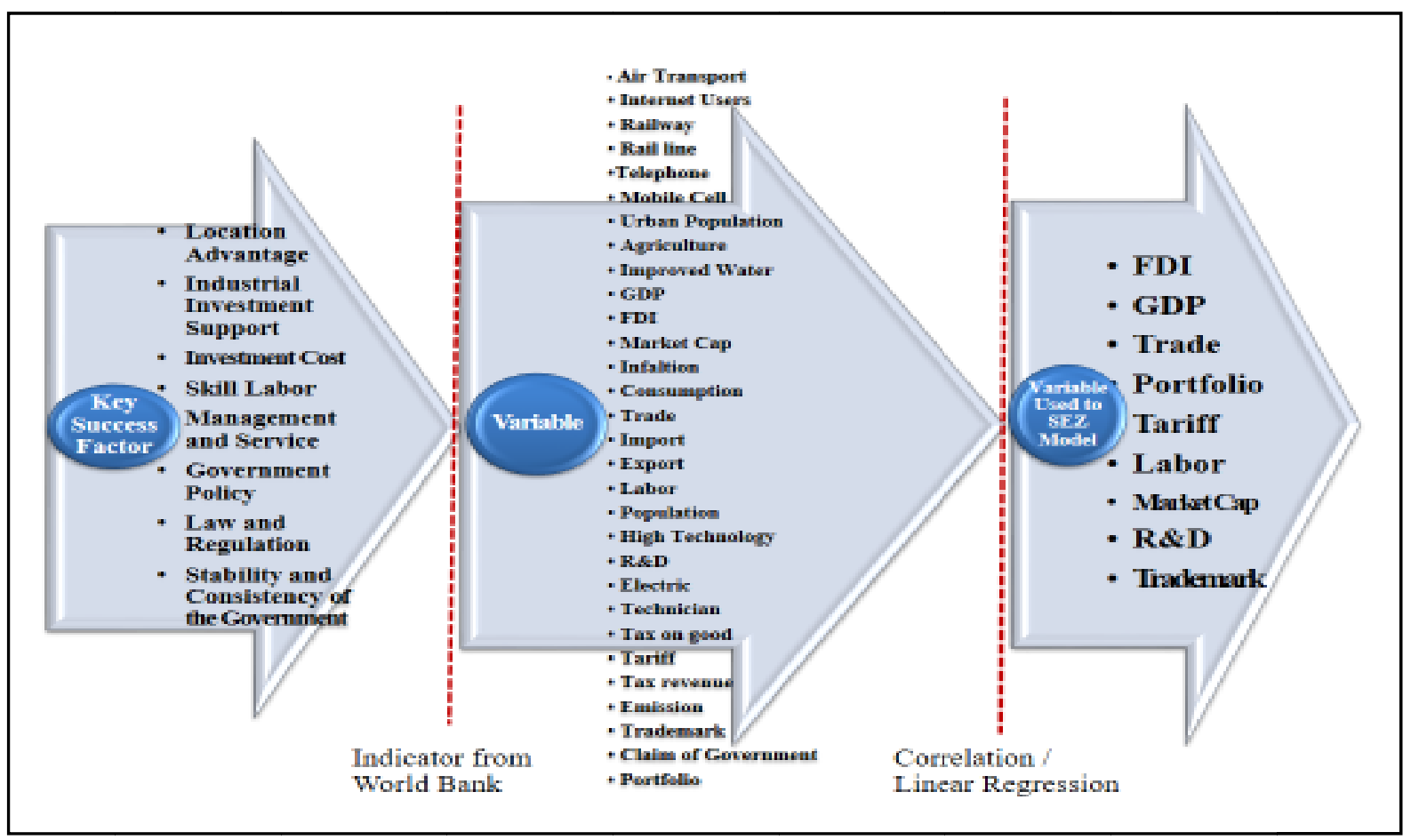

Figure 2. Process of finding variable

Type Test of Significance on Each Variable Affecting the Special Economic Zone Establishment is done using the data of factors which have passed the correlation test with the Linear Regression: Least Square (NLS and ARMA) Program Eviews, which conclude the results of each country consisting of 12 Countries and the details are shown in Table 2. The success of Special Economic Zone establishment is based on the Foreign Direct Investment (FDI).

Hypothesis

$\mathrm{H}_{0}$ : FDI does not affect the success of Special Economic Zone.

$\mathrm{H}_{1}$ : FDI affect the success of the Special Economic Zone.

$$
\begin{aligned}
\mathrm{Y}=\mathrm{FDI} & \\
& +++++++ \\
\mathrm{QX}_{\mathrm{t}}= & \mathrm{f}\left(\mathrm{Lo}_{\mathrm{t}}, \mathrm{In}_{\mathrm{t}}, \mathrm{Co}_{\mathrm{t}}, \mathrm{Sk}_{\mathrm{t}}, \mathrm{Ma}_{\mathrm{t}}, \mathrm{Go}_{\mathrm{t}}, \mathrm{La}_{\mathrm{t}}, \mathrm{St}_{\mathrm{t}}\right)
\end{aligned}
$$

The level statistics significance: $\alpha=0.05$ at the confidence level of $95 \%$.

According to the hypothesis test, the FDI is tested with the X value $=\{$ Lo: GDP, In: Market, Co: Trade, Sk: Labor, Ma: RD, Go: Tariff, Lo: Trademark, St: Portfolio $\}$ of each type, the result found that there were 10 countries from the total of 12 countries which refuse the hypothesis. Two countries which accept the hypothesis are Japan and Malaysia. This can be concluded that the FDI results affect the origination of Special Economic Zone.

\section{Take Key Success Factor to Run with Ordinary Least Squares}

Take eight factors to run with OLS regression model from the equation:

$$
\hat{Y}=\beta_{0}+\beta_{1} X+\varepsilon
$$




$\begin{array}{lll}\text { The } & \log (\text { FDI })=\alpha+\beta_{1} \log (\text { GDP })+\beta_{2} \log (\text { Market }) & \text { variable can } \\ \text { be } & +\beta_{3} \log (\text { Trade })+\beta_{4} \log (\text { Labor })+\beta_{5} \log (\text { RD })-\beta_{6} \log (\text { Tariff }) & \text { determined to } \\ \text { substitute } & +\beta_{7} \log (\text { Trademark })+\beta_{8} \log (\text { Portfolio }) & \text { as follows: }\end{array}$

1. $\mathrm{FDI}=$ Foreign direct investment

2. GDP $=$ Gross Domestic Product

3. Market $=$ Market Capitalization of listed Companies

4. Trade $=$ Trade

5. Labor $=$ Labor Force

6. $\mathrm{RD}=$ Researchers in $\mathrm{R} \& \mathrm{D}$

7. Tariff $=$ Tariff rate

8. Trademark $=$ Trademark Application

9. Portfolio $=$ Portfolio Equity

Table 2 exhibits the result of test eight factors to run with OLS regression model.

Table 2

Result of Test Eight Factors to Run with OLS Regression Model

\begin{tabular}{|c|c|c|}
\hline Country & $\begin{array}{l}\text { Independent Variable Explains } \\
\text { Dependent Variable (\%) }\end{array}$ & Factors Result \\
\hline USA & 99 & $\begin{array}{l}\text { The first factors which should be considered and focus on include investment cost, } \\
\text { industrial investment support, labor force, and management and service. }\end{array}$ \\
\hline China & 98 & $\begin{array}{l}\text { The first factor which should be focused on is the skilled labor; second focused factor } \\
\text { include the location advantage and macroeconomics of country. }\end{array}$ \\
\hline India & 99 & $\begin{array}{l}\text { The first factor which should be considered and focus on is Management and the Stability } \\
\text { and Consistency of the Government. }\end{array}$ \\
\hline Thailand & 66 & $\begin{array}{l}\text { The first factors which should be considered are the management and service, location } \\
\text { advantage and macroeconomic of Country, stability and consistency of the government. }\end{array}$ \\
\hline \multicolumn{3}{|c|}{ Strategy of Thailand: Forecasting of all 8 Factors. For the next 6 years, if the growth increases at 6\%. } \\
\hline Thailand & 93 & $\begin{array}{l}\text { The further factors which should be considered and focused on include law and regulation } \\
\text { stability, and industrial investment. }\end{array}$ \\
\hline
\end{tabular}

Source: Simulation

\section{Thai Case}

Table 2 is the supply equation of the Foreign Direct Investment. It can be seen that from this equation, the independent variables can explain the dependent variables for $66 \%$ and can explain that the independent variables which include GDP, market capitalization, trade, labor, R\&D, tariff, trademark, and Portfolio can explain the change of dependent variables, which is, FDI, for $77 \%$, and for the rest of $\Sigma \varepsilon \%$, of the FDI change, it is caused by other factors [considered by $\mathrm{R}^{2}$ value], and the F-statistic value is the hypothesis test the totally calculated coefficient whether it is equal to zero. It appears that the calculated coefficient has the value different from zero at the confidence level at $95 \%$ [considered

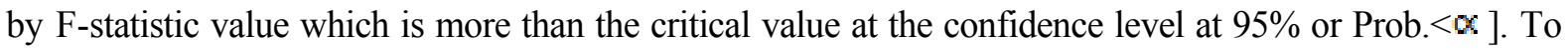
this end, it can be indicated that this equation has no problem of autocorrelation (Johnson, 2000). From this result of test eight factors to run with OLS regression model, if the Thailand wants to establish Special Economic Zone to make the economic growth, the first factor which should be considered is the management and service; following this, the second are location advantage and macrocosmic of country and stability and consistency of the government, respectively. 


\section{Strategy of Thailand}

According to the running of equation to find the relationship of the variables, it is found that if Thailand requires the success of Special Economic Zone establishment, it is necessary to have the stimulation of Foreign Direct Investment by emphasizing the good management and service, appropriate of location advantage and macrocosmic of country, and the creation of governmental security and stability. Hence, there has been the determination of strategies for economic development of Thailand. This is done by creating the forecasting of all 8 variables. By reviewing all scenarios and applying 8 forecasting factors for 6 years from now, it is still questionable how the specific economic zone would be impacted by the growth rate at $1 \%$ annually. With the growth rate at $6 \%$ per year, Foreign Direct Investment will be increased from $66 \%$ to $93 \%$, it could be considered as the most optimal point for Thailand economy. Thailand Special Economic Zone might face the declining growth rate if the growth rate excesses $6 \%$ per year.

According to Table 2, it can be seen that the value of the variables equation resulting from running 4 countries include United State of America (USA) and China, the countries which established the Special Economic Zone successfully (Shenzhen Special Economic Zone), whereas India is the country unsuccessful in establishing the Special Economic Zone due to the problem of land management. The relationship value depends on the variables value used for running. It can be seen that the countries which developed the Special Economic Zone mostly emphasize the management and service. The result is in accordance with the literature reviews of Special Economic Zone establishment for United State of America, China, and India. For Thailand to have successful Economic Zones, it has to emphasize the management and service, location advantage and macroeconomic of country, and stability and consistency of the government.

\section{Sensitivity Analysis}

After having estimated the coefficient value, the expected value of dependent variables can be calculated depending on the independent variables (Conditional Expected Value of $Y: Y^{\wedge}$ ). In the EViews, they are called 'Fitted', then they are brought to compare with the actual Y, and find the difference between these two values, the value of errors for data processing of 'Residual' according to the Table 3.

Table 3 shows the result of sensitivity.

Table 3

Result of Sensitivity

\begin{tabular}{ll}
\hline Country & Sensitivity Test \\
\hline USA & $-0.02-0.04$ \\
China & $0.2-0.20$ \\
India & $-0.8-0.04$ \\
Thailand & $-0.7-0.7$ \\
\hline
\end{tabular}

Source: Simulation

Table 3 shows all countries which have the appropriateness of data resulting from the equation processing (Actual), prediction equation (Fitted), and the error of both values (Residual). It can be seen that the value of prediction error is not over 1 . Hence, it can be inferred that the analysis results are not much different from the former one, or there is minor difference at the level which means it is not affected practically. Therefore, it can be said that the data used for processing and equation is stable not sensitive and the analysis results are credible and correct. 
Types and areas appropriate for the Special Economic Zone establishment in Thailand to support of ASEAN Economic Community (AEC)

The data analysis of the appropriate areas for Special Economic Zone establishment in all 28 provinces regarded as the big city, border city, and industrial city (Bangkok, Nonthaburi, Phuket, Surat Thani, Chiang Mai, Prachuab Kiri Khan, Nakhon Ratchasrima, Nakhon Phatom, Koan Kaen, Krabi, Tak, Mukdahan, Srakaew, Trat, Songkhla, Nongkai, Kanchanaburi, Narathiwas, Chiangrai, Nakhon Panom, Udonthani, Chonburi, Samutprakarn, Pathumthani, Rayong, Samutsakorn, Phra Nakhon Sriayuttaya, and Saraburi) is considered from 4 variables which include the number of new business registration of juristic person separated as each province, gross provincial products, the number of capitals registration of juristic person separated as each province, and the number of population in the province. In addition, 4 factors determined the variables for running the equation. The variables can create the OLS regression model: Linear Regression by determining that the selection of areas for Special Economic Zone establishment is based on the number of capitals for registration of juristic person separated as each province.

Hypothesis

$\mathrm{H}_{0}$ : Capital does not affect the area which cause the Special Economic Zone.

$\mathrm{H}_{1}$ : Capital affect the area which cause the Special Economic Zone.

$\mathrm{Y}=$ Capital

$\mathrm{QX}_{\mathrm{t}}=\mathrm{f}\left(\mathrm{GPP}_{\mathrm{t}}, \mathrm{NEW}_{\mathrm{t}}, \mathrm{POP}_{\mathrm{t}}\right)$

The level statistics significance: $\alpha=0.05$ at the confidence level of $95 \%$.

$$
\begin{aligned}
& \log (C A P I T A L)=\alpha+\beta_{1} \log (G P P)+\beta_{2} \log (N E W) \\
& +\beta_{3} \log (P O P) \\
& \hat{Y}=\beta_{0}+\beta_{1} X+\varepsilon
\end{aligned}
$$

The Variables are determined as follow:

Capital $=$ The number of capitals registered of juristic person separated as each province GPP $=$ Gross provincial product (Bath)

$\mathrm{NEW}=$ The number of new business registered of juristic person separated as each province $\mathrm{POP}=$ The number of population (1,000 persons) separated as each province

The variables for running the equation are determined by 4 factors. There are only 8 provinces, namely Bangkok, Chonburi, Pathum Thani, Phuket, Srakaew, Suratthai, Trat, and Udonthani which can establish the Special Economic Zones. Most of the variables have the relationship in the same direction which focus on the new business and gross provincial product, whereas the factor that affects the least is Population. The researcher concludes the relationship between the areas and types appropriate for each area. The details are shown in Table 4. 
Table 4

Conclusion of the Appropriate Types and Areas for the Special Economic Zone in Thailand

\begin{tabular}{|c|c|c|c|}
\hline Area & Appropriate Industry & Type Analysis for SEZ & Type SEZ \\
\hline Bangkok & $\begin{array}{l}\text { Complete Medication } \\
\text { Hospital and Healthy/ Trading }\end{array}$ & Healthy Center/ Design Sourcing Trading & $\begin{array}{l}\text { Specialized Zone: Healthy Zone/ } \\
\text { Economic and Technology Zone }\end{array}$ \\
\hline Trat & Food Processing & Manufacture for Export and border trade & Export Processing Zone \\
\hline Pathumthani & Digital Robot & Manufacture for Export & Export Processing Zone \\
\hline Chonburi & $\begin{array}{l}\text { Modern Automobile } \\
\text { Genius Electronics }\end{array}$ & Manufacture for Export & Export Processing Zone \\
\hline Phuket & $\begin{array}{l}\text { Tourism of Good Income Group } \\
\text { and Qualitative Tourism } \\
\text { Transportation }\end{array}$ & Tourism Service and HUB Logistics Service & Freeport Zone \\
\hline Suratthani & $\begin{array}{l}\text { Food Processing } \\
\text { Rubber and Palm Oil Processing }\end{array}$ & Manufacture for Export & Export Processing Zone \\
\hline Udonthani & International Wholesales & Border Trade & $\begin{array}{l}\text { Specialized Zone : Border } \\
\text { Economic Cooperation Zone }\end{array}$ \\
\hline Srakaew & Biofuels and Biochemicals & Manufacture for Export and Border Trade & $\begin{array}{l}\text { Specialized Zone : Border } \\
\text { Economic Cooperation Zone }\end{array}$ \\
\hline
\end{tabular}

Source: The Office of Small and Medium Enterprise Promotion (OSMEP) and Fiscal Policy Research Institute Foundation, and Analysis Data by Researcher

\section{Discussion and Conclusion}

According to the results, the key success factors can be rearranged in importance, namely location advantage and macroeconomics of country, stability and consistency of the government, industrial investment support, investment cost, skill level and availability of human resource, management and service, law and regulations, and government policy, respectively. The key success factors which Thailand should emphasize are management and service, location advantage and macroeconomic of country, and stability and consistency of the government. The appropriate areas for establishing the Special Economic Zone in Thailand in order to support of ASEAN Economic Community (AEC) are Bangkok, Trat, Pathumthani, Chonburi, Phuket, Suratthani, Udornthani, and Srakaew, respectively and the type of Special Economic Zone appropriate for Thailand is Specialized Zone: (Healthy Zone/ Economic and Technology Zone/ Border Economic Cooperation Zone)/ Export Processing Zone/ Freeport Zone.

The Mathematic Model can be analyzed for establishing the Special Economic Zone of each country for the benefits of the country's development including the ability to realize the competitive ability with neighboring countries. However, the disadvantage is that if the data were browsed incorrectly, it might cause the analysis results to deviate from the reality. For the benefits of this model, it can analyze the information of the Special Economic Zone establishment to be successful by selecting the data from the World Bank to analyze and got 8 major factors which will be most beneficial for the country's development. If there is the extended development, other variables can be added to make the models more complete such as ease of doing business and logistics performance index. In this way, the model can be more complete and it will be able to be applied to analyze the growth of country in other aspects as well.

\section{References}

Anitha, R. (2000). Foreign direct investment and economic growth in India. International Journal of Marketing, Financial Service \& Management Research.

Aradhna, A. (2007). Impact of special economic zones on employment and human development (Working Paper No. 194). Indian Council for Research on International Economic Relations. 
Bernsein, A. (2012). Special economic zones: Lessons for South Africa from international evidence and local experience edited proceedings of a round table convened by the center for development and enterprise. South Africa, Johannesburg: The Centre for Development and Enterprise.

Dobronogov, A., \& Farole, T. (2012). An economic integration zone for the east African community: Exploiting regional potential and addressing commitment challenges. Africa Region: The Poverty Reduction and Economic Management Unit, The World Bank.

Farole, T. (2008). Special economic zones performance, lessons learned, and implications for zone development: The multi-donor investment climate advisory service managed (FIAS), The International Finance Corporation (IFC) and supported by the Multilateral Investment Guarantee Agency (MIGA) and the World Bank (IBRD). Washington DC: The World Bank.

Farole, T., \& Akinici, G. (2011). Special economic zones: Progress, emerging challenges, and future directions. Washington D. C.: The International Bank for Reconstruction and Development, The World Bank.

Guo, J. (2010). The effects of tax rates on foreign direct investment in China, school of economic and business administration, Beijing Normal University, China. The Journal of International Management Studies, 5(1), 31-37.

Jiang, B., Sun, Z., \& Liu, M. (2010). China's energy development strategy under the low-carbon economy. Energy, 35(11), 4257-4264.

Johnson, R. R. (2000). A guide to using Eviews with using econometrics: A Practical Guide. USA: University of San Diego.

Raheem, A. (2011). Impact of Special Economic Zone (SPZ) on human development and poverty reduction: An Indian. Chennai: Department of Economics, The New College, University of Madras.

Ray, S. (2012). Impact of foreign direct investment on economic growth in India: A co integration analysis: Advances in Information Technology and Management (AITM). India: Shyampur Siddheswari Mahavidyaya, University of Calcutta.

Tang, S., Selvanathan, E. A, \& Selvanathan, S. (2008). Foreign direct investment, domestic investment, and economic growth in China (Research Paper No.2008/19). UNU Wider: United Nations University.

Tsuneishi, T. (2008). Development of border economic zones in Thailand: Expansion of border trade and formation of border economic zones. JETRO: Institute of Developing Economics.

Wang, J. (2010). The economic impact of special economic zones: Evidence from Chinese municipalities. China: Hong Kong University of Science and Technology.

Wang, W., Ren, L., Guo, Q., \& Chen, T. (2012). Predicating energy demand and carbon emissions of the yellow river delta high-efficiency eco-economic zone. Energy Procedia, 14, 229-234.

Zhu, J. (1994). Changing land policy and its impact on local growth: The experience of the Shenzhen special economic zone, China, in the 1980s. Urban Studies, 31(10), 1611-1623. 